\title{
Severe metallosis following oxidised zirconium wear in total hip arthroplasty
}

\author{
Erato Gkouliopoulou, ${ }^{1}$ Filon Agathangelidis, ${ }^{1}$ Themistoklis Vampertzis, ${ }^{2}$ \\ Thomas Ntovas ${ }^{3}$
}

${ }^{1}$ General Hospital of Veria, Veria, Greece

${ }^{2}$ Orthopaedics Department, Agios Pavlos General Hospital of Thessaloniki, Thessaloniki, Greece

${ }^{3}$ Orthopadic Department, General Hospital of Veria, Veria, Greece

\section{Correspondence to} Filon Agathangelidis, fagath@gmail.com

Accepted 20 October 2016
CrossMark

To cite: Gkouliopoulou $\mathrm{E}$, Agathangelidis $\mathrm{F}$,

Vampertzis T, et al. BMJ Case Rep Published online: [please include Day Month Year] doi:10.1136/bcr-2016218025

\section{DESCRIPTION}

We present a case of a man aged 81 years who underwent a primary cementless total hip arthroplasty. Eight years after the index surgery, failure of the arthroplasty was revealed by the presence of the radiographic 'cloud sign' (figure 1). The original components used were the R3 acetabular cup with a Synergy femoral stem, highly crossed linked polyethylene liner and an oxidised zirconium (Oxinium) femoral head (Smith \& Nephew Synergy, Memphis, Tennessee, USA). The initial investigation included a CT scan, full blood tests and a tissue biopsy which revealed no malignancy. Subsequently, during revision surgery, there was extensive osteolysis with metallosis. There was black staining of the periprosthetic soft tissues and the hip pseudocapsule was filled with thick black fluid (figure 2). There was severe wear of the femoral head and the polyethylene liner. Following debridement and removal of the components, a revision cementless stem and acetabular cup was used to reconstruct the hip joint.

The cloud sign in the plain radiographs-also known as the bubble sign-is an indication of soft tissue metallosis. ${ }^{1}$ The findings are usually subtle

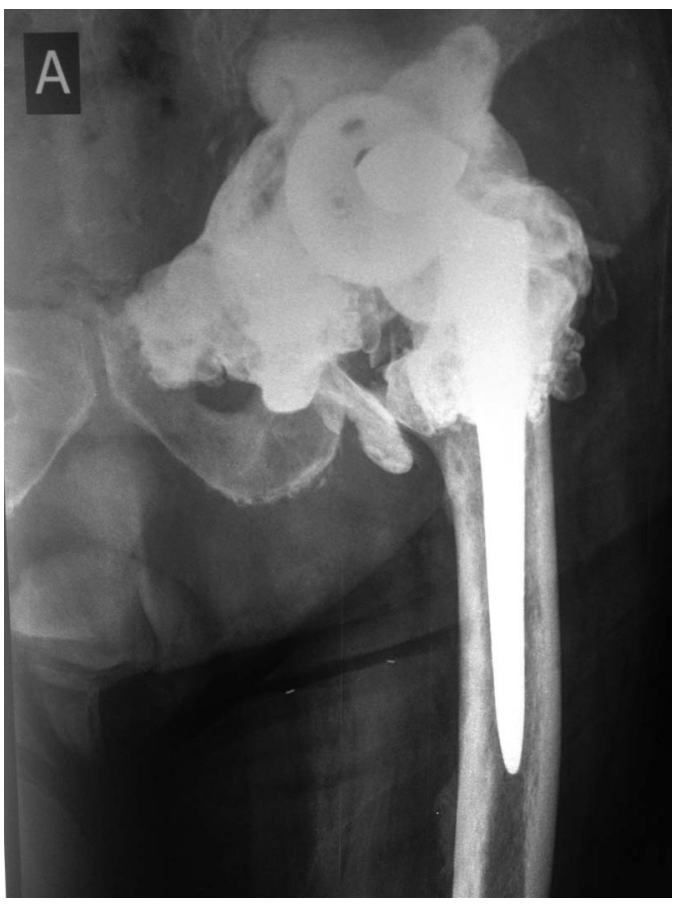

Figure 1 Anteroposterior plain radiograph, without use of contrast medium, showing an extensive cloud sign of the periprosthetic tissues, failure of the acetabular cup and wear of the oxinium femoral head.

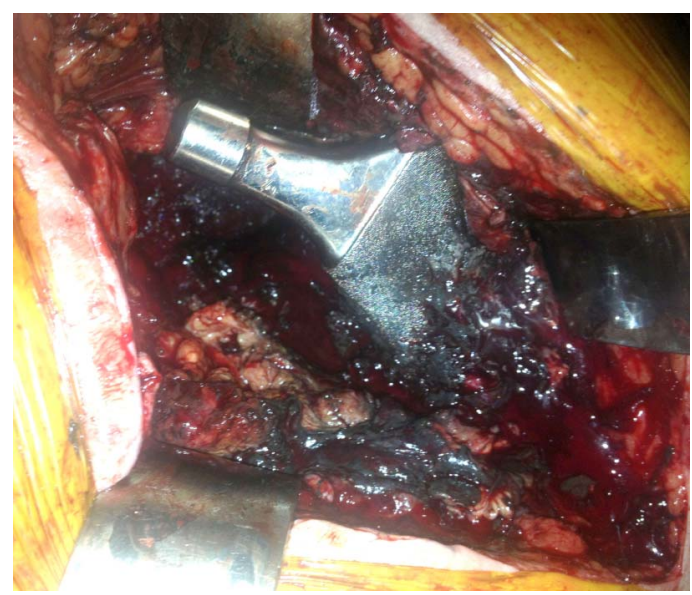

Figure 2 Intraoperative photograph during revision surgery. There is black staining of the periprosthetic tissues and osteolysis around the peritrochanteric area.

and the debris is well tolerated by the patients. A few cases with characteristic radiographic findings are reported in the literature, but to the best of our knowledge, the present case is the most impressive due to the extent of the metallosis. ${ }^{2}{ }^{3}$ Oxidised zirconium is a metallic alloy with a ceramic surface that combines the best of metal and ceramics. However, if the outer surface of the head is damaged, then rapid destruction of the head can occur.

\section{Learning points}

- The cloud sign in a plain hip and knee radiograph is an indication of soft tissue metallosis.

- When the surface of an oxidised zirconium femoral head is damaged, rapid wear of the metallic alloy of the core can occur.

- The metallic debris is well tolerated by the patient. Patients with an oxidised zirconium hip or knee replacement need regular follow-up.

Contributors EG wrote the manuscript. FA wrote the manuscript and reviewed the literature. He also assisted in surgery. TV reviewed the literature and the manuscript. TN is the senior author and performed the surgery.

Competing interests None declared.

Patient consent Obtained.

Provenance and peer review Not commissioned; externally peer reviewed. 


\section{REFERENCES}

1 Su EP, Callander PW, Salvati EA. The bubble sign: a new radiographic sign in total hip arthroplasty. J Arthroplasty 2003;18:110-2.

2 Tribe $H$, Malek S, Stammers J, et al. Advanced wear of an Oxinium ${ }^{\mathrm{TM}}$ femoral head implant following polyethylene liner dislocation. Ann R Coll Surg Engl 2013;95:e133-5
3 Malizos K, Roidis NT, Poultsides L, et al. Protrusio of a ceramic femoral head through the acetabular metallic shell, extensive metallosis and 'bubble sign'. Orthopedics 2009;32:128.

Copyright 2016 BMJ Publishing Group. All rights reserved. For permission to reuse any of this content visit http://group.bmj.com/group/rights-licensing/permissions.

BMJ Case Report Fellows may re-use this article for personal use and teaching without any further permission.

Become a Fellow of BMJ Case Reports today and you can:

- Submit as many cases as you like

- Enjoy fast sympathetic peer review and rapid publication of accepted articles

- Access all the published articles

- Re-use any of the published material for personal use and teaching without further permission

For information on Institutional Fellowships contact consortiasales@bmjgroup.com

Visit casereports.bmj.com for more articles like this and to become a Fellow 